\title{
A Comparative Study to Assess the Fetal and Placental Outcome among Anaemic and Non-Anaemic Mothers of Selected Hospital of District Mohali, Punjab, India
}

\author{
Anupama Sharma ${ }^{1 *}$, Madan Lal ${ }^{1}$, Vill Malehri ${ }^{1}$ and P.O. Dangar ${ }^{2}$ \\ ${ }^{1}$ Mata sahib kaur College of nursing, Mohali, Punjab, India \\ ${ }^{2}$ The-Ghumarwin, Dist-Bilaspur H.P.174023, India \\ *Corresponding author
}

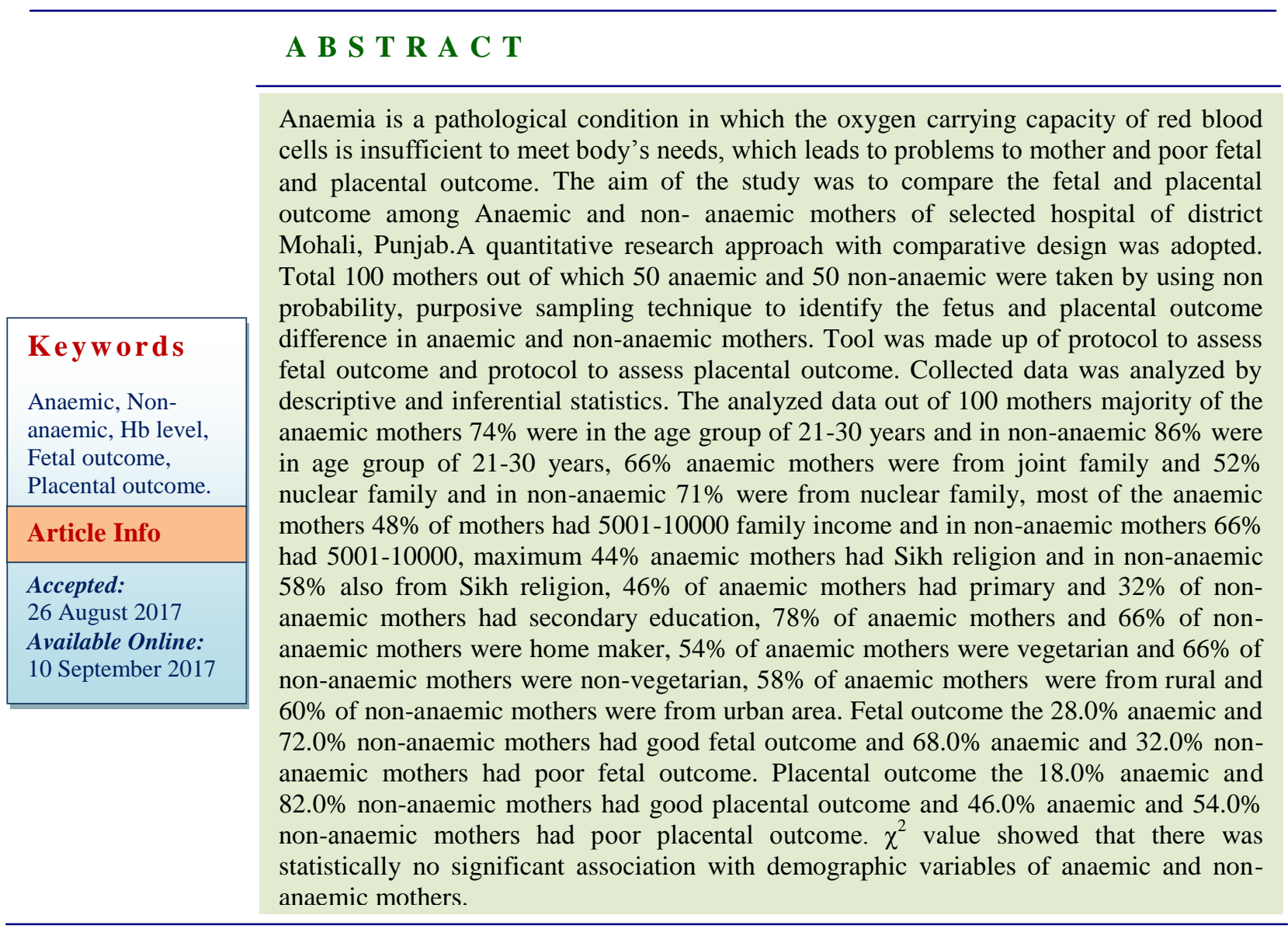

\section{Introduction}

Pregnancy is the period from conception to birth. Pregnancy begins with fertilization of ovum, a sperm and subsequent implantation of the egg that leads to the conception.
Pregnancy may be determined by cessation of menses, enlarged uterus and positive results of pregnancy are the pregnancy test. High risk pregnancy one of the greater risk to the 
mother and on her baby. The risk is complicated by factors that adversely affect the pregnancy outcome. Some of the high risk factors in reproductive history are Anaemia, Pre-eclampsia, Eclampsia, Grand multi parity, medical surgical disorders associated with pregnancy, previous still birth and previous preterm labour etc. ${ }^{1}$

In pregnancy, anaemia is a condition in which the haemoglobin level is lower than the one third of normal level. Anaemia is not a specific disease but a sign of underlying disorders. It is of two type- Hypoprolifrative anaemia: in this the bone marrow cannot produce adequate number of erythrocytes.

It may results from bone marrow damage due to side effect of any medication or lack of factors like iron, folic acid etc.

Haemolytic anaemia: premature destruction of erythrocytes result in the liberation of haemoglobin from the erythrocyte destruction in to the plasma ${ }^{2}$

During antenatal period mother needs an extra attention about her diet to get healthy baby. If any alterations in health of mother like minor disorders like nausea, vomiting and other

minor illnesses may lead to anaemia. Anaemia is not disease but it is clinical condition characterized by deficiency of nutrients especially iron and vitamins that requires immediate attention by the health personnel to reduce morbidity and mortality rate of mother and fetus. Hence it is considered as a life threatening condition. ${ }^{3}$

Anaemia during pregnancy is most common and considerable health problem in developing countries, despite the fact that most of anaemia cases seen in pregnancy and it is largely preventable and easily cured if detected in time it still continue to be a common cause of mortality and morbidity in India. Factors that are often reported to influence maternal anaemia are low socioeconomic status, less mother's age, multiple pregnancy, pre-pregnancy underweight, faulty dietetic habit, faulty absorption mechanism, increased iron loss (through sweat, repeated pregnancies, excessive blood loss during menstruation) inadequate supply of nutrients like iron, folic acid and vitaminB $B_{12}$, proteins, amino acids, vitamins $\mathrm{A}, \mathrm{C}$ and other vitamins of B-complex group. ${ }^{4}$

Anaemia affects placenta and fetal outcome dreadfully. Placenta is a developing organ during pregnancy for providing nutrition, oxygen supply for the fetus and to eliminate excretory wastes, acts as protective barrier.

The placental outcome in healthy mother are as follows the timing for delivery of placenta is within 15 minutes, weight of placenta is $500 \mathrm{gm}$, shape of placenta is oval in shape, diameter is $15 \mathrm{~cm}$, thickness is $1.5 \mathrm{~cm}$,number of cotyledons is 20,colour is thick white and red, length of umblical cord is $50 \mathrm{~cm}$, vessels are three 2 arteries and one vein and insertion of the cord on the fetal surface is central insertion.

If the placenta has affected due to anaemia, it adversely effects on the growth of the fetus. Neonates can be having pathological conditions like, birth asphyxia, prematurity, IUGR, low birth weight and also the placenta varies in its measures that includes its weight, morphometry, number of cotyledons and its thickness.

The normal parameters of healthy new-born is the APGAR score is 7-10, weight is 2.6-3.1 $\mathrm{kg}$, temperature is $99.5^{\circ} \mathrm{F}$, crown-heal length is $50 \mathrm{~cm}$, crown-rump length is $35 \mathrm{~cm}$, head circumference is 33-35 cm, chest circumference is $30-33 \mathrm{~cm}$ and all the reflexes like rooting, glabeller, grasp, moro, suckling 
and swallowing should be present in normal newborn. ${ }^{5}$ Hence a good fetal outcome depends on mothers health and her diet during antenatal period.

The aim of the study is to compare the fetal and placental outcome among Anaemic and non- anaemic mothers of selected hospital of district Mohali, Punjab, India.

The Objectives of this study to assess the fetal outcome in anaemic and non-anaemic mothers. The placental outcome in anaemic and non-anaemic mothers. To compare the fetal outcome and placental outcome in anaemic and non-Anaemic mothers. Also determine association between fetal outcome and placental outcome with selected demographic variables in both anaemic and non-anaemic mothers.

\section{Assumption}

There will be significant difference between fetal and placental outcome among anaemic and non-anaemic mothers at selected hospital district Mohali, Punjab.

\section{Delimitations}

The present study is delimited to the mothers who are:

This study is delimited to selected hospital of Mohali.

This study is delimited to anaemic and nonanaemic mothers.

\section{Materials and Methods}

In present study, a quantitative approach with comparative research design was adopted. By Purposive sampling technique 100 mothers (50 anaemic 50 non-anaemic) were selected. Data was collected by protocol to assess the fetal and placental outcome in anaemic and non-anaemic mothers. Analysis of data was done using descriptive and inferential statistics. A study was conducted in the month of March 2016 Formal written permission was obtained from the SMO of civil hospitals of Mohali and Kharar. After discussing the purpose and objectives of the study. Analysis and interpretation of data was done according to objectives of the study by using descriptive and inferential statistics.

\section{Ethical consideration}

With the view of ethical consideration the researcher has taken permission from Principal of Mata Sahib Kaur College of nursing Mohali. After that the researcher has discussed the type and purpose of the study with the SMO of civil hospitals of Mohali and Kharar and written permission were obtained. Also the mothers were explained about the purpose of the study and verbal consent was taken from them for their participation in study. They were explained about the right to refuse from participating in the study.

\section{Results and Discussion}

\section{Major findings of the study}

\section{Section I: Findings related to socio demographic variables}

The majority of the anaemic mothers $74 \%$ were in the age group of 21-30 years and in non-anaemic $86 \%$ were in age group of 21-30 years, $66 \%$ anaemic mothers were from joint family and $52 \%$ nuclear family and in nonanaemic $71 \%$ were from nuclear family, most of the anaemic mothers $48 \%$ of mothers had 5001-10000family income and in nonanaemic mothers 66\% were 5001-10000, maximum 44\%anaemic mothers belong to Sikh religion and in non-anaemic $58 \%$ also from Sikh religion, $46 \%$ of anaemic mothers had primary and $32 \%$ of non-anaemic 
mothers had secondary education, $78 \%$ of anaemic mothers and $66 \%$ of non-anaemic mothers were home maker, $54 \%$ of anaemic mothers were vegetarian and $66 \%$ of nonanaemic mothers were non-vegetarian, $58 \%$ of anaemic mothers were from rural and $60 \%$ of non-anaemic mothers were from urban area (Table 1).

\section{Section II: Findings related to clinical variables}

The majority all anaemic mothers $100 \%$ had $<10 \mathrm{gm} \%$ and all non-anaemic mothers $100 \%$ had $\geq 10$ gm $\%, 54 \%$ anaemic mothers and $50 \%$ non-anaemic mothers were multigravida, $52 \%$ anaemic mothers and $62 \%$ non-anaemic mothers had girl boy, $74 \%$ anaemic mothers and $88 \%$ non-anaemic mothers had at-term delivery (Table 2).

\section{Section III: Findings related to fetal outcome}

The majority, it was found that $80 \%$ of anaemic mothers and $96 \%$ non-anaemic mother's baby had no depression, $68 \%$ anaemic mothers and $96 \%$ non-anaemic mothers had baby weight $2.5-3.1 \mathrm{~kg}, 94 \%$ anaemic mothers baby had $96.8-97.7^{\circ} \mathrm{F}$ and $96 \%$ non-anaemic mothers baby had temperature $96.8-97.7^{\circ} \mathrm{F}, 68 \%$ anaemic and $96 \%$ non-anaemic mother's baby had crownheel length 50-52c.m, 70\% anaemic and 94\% non-anaemic mother's baby had headcircumference 33-35 c.m, 92\% anaemic and $90 \%$ non-anaemic mother's baby had chestcircumference 30-33c.m, 100\% anaemic and non-anaemic mother's baby had no congenital malformation, $52 \%$ anaemic and 52\% nonanaemic mothers had girl baby (Table 3 ).

\section{Section IV: Findings related to placental outcome}

The majority, it was found that $90 \%$ anaemic and $100 \%$ non-anaemic mothers delivered their placenta at 5-20 minutes,50\% anaemic and $80 \%$ non-anaemic mothers had $500 \mathrm{gm}$ placental weight, $88 \%$ anaemic and $96 \%$ nonanaemic mothers had discoid shape placneta,76\% anaemic and $92 \%$ non-anaemic mothers had 15-20c.m diameter of placenta, $72 \%$ anaemic and $90 \%$ non-anaemic had 3c.m thickness of placenta, $100 \%$ anaemic and $100 \%$ non-anaemic mothers had 15-20 lobes in their placenta, $72 \%$ anaemic and $92 \%$ non-anaemic mothers placenta had complete placenta, $90 \%$ anaemic mothers and 94\% non -anaemic mothers had dull red and grayish colour of their placenta, $100 \%$ anaemic and non-anaemic mothers had normal placenta, 90\% anaemic and 96\% nonanaemic mothers had length of umblical cord normal, $100 \%$ anaemic and non-anaemic mothers had presence of Wharton's jelly in their cord, $100 \%$ anaemic and non-anaemic mothers had two arteries and one vein in the vessels of umblical cord,96\% anaemic and $100 \%$ non-anaemic had central insertion of cord on fetal surface (Table 4). Section V: Findings related to the
comparison

In anaemic mothers out of 50 mothers $28.0 \%$ had good fetal outcome and $72.0 \%$ had poor fetal outcome and in non-anaemic mothers out of 50 mothers $68.0 \%$ had good fetal outcome and $32.0 \%$ had poor fetal outcome. 
Table.1 Frequency and percentage distribution of anaemic and non-anaemic mothers according to their socio-demographic variables

$\mathrm{N}=100$

\begin{tabular}{|c|c|c|c|c|c|c|}
\hline S. No & Socio demographic variables & \multicolumn{2}{|c|}{$\begin{array}{c}\text { Anaemic } \\
\left(\mathbf{n}_{1}=\mathbf{5 0}\right)\end{array}$} & \multicolumn{2}{|c|}{$\begin{array}{c}\text { Non-anaemic } \\
\left(\mathbf{n}_{2}=\mathbf{5 0}\right)\end{array}$} & $\chi^{2}$, df, p-value \\
\hline 1. & Age(in years) & $\mathbf{f}_{1}$ & $\%$ & $\mathbf{f}_{2}$ & $\%$ & \multirow{4}{*}{$.56^{\mathrm{NS}}, 4, .96$} \\
\hline & $\leq 20$ & 11 & 22 & 03 & 06 & \\
\hline & $21-30$ & 37 & 74 & 43 & 86 & \\
\hline & $\geq 31$ & 02 & 04 & 04 & 08 & \\
\hline \multirow[t]{3}{*}{2.} & \multicolumn{5}{|l|}{ Type of family } & \multirow{3}{*}{$.25^{\mathrm{NS}}, 1, .61$} \\
\hline & Nuclear & 17 & 34 & 26 & 52 & \\
\hline & Joint & 33 & 66 & 24 & 48 & \\
\hline \multirow[t]{5}{*}{3.} & \multicolumn{5}{|l|}{ Total family income per month } & \multirow{5}{*}{$\begin{array}{l}1.93^{\mathrm{NS}}, 6 \text {, } \\
.92\end{array}$} \\
\hline & $\leq 5000$ & 20 & 40 & 07 & 14 & \\
\hline & $5001-10000$ & 24 & 48 & 33 & 66 & \\
\hline & $10001-15000$ & 5 & 10 & 10 & 20 & \\
\hline & $\geq 15001$ & 01 & $\mathbf{0 2}$ & 00 & 00 & \\
\hline \multirow[t]{6}{*}{4.} & \multicolumn{5}{|l|}{ Religion } & \multirow{6}{*}{$3.10^{\mathrm{NS}}, 9, .96$} \\
\hline & Hindu & 11 & 22 & 17 & 34 & \\
\hline & Sikh & 22 & 44 & 29 & 58 & \\
\hline & Muslim & 11 & 22 & 03 & 06 & \\
\hline & Christian & 02 & 04 & 01 & $\mathbf{0 2}$ & \\
\hline & Others & 04 & 08 & 01 & 02 & \\
\hline \multirow[t]{5}{*}{5.} & \multicolumn{5}{|l|}{ Educational status of mother } & \multirow{5}{*}{$7.9^{\mathrm{NS}}, 9, .63$} \\
\hline & No formal education & 16 & 32 & 15 & 30 & \\
\hline & Primary education & 23 & 46 & 14 & 28 & \\
\hline & Secondary education & 09 & 18 & 16 & 32 & \\
\hline & Sen. Sec. and above & 02 & 04 & 05 & 10 & \\
\hline \multirow[t]{5}{*}{6.} & \multicolumn{5}{|l|}{ Occupation } & \multirow{5}{*}{$3.78^{\mathrm{NS}}, 9, .92$} \\
\hline & Private job & 07 & 14 & 11 & 22 & \\
\hline & Government job & 02 & 04 & 03 & 06 & \\
\hline & Home maker & 39 & 78 & 33 & 66 & \\
\hline & Own business & 02 & 04 & 03 & 06 & \\
\hline \multirow[t]{3}{*}{7.} & Dietary habits & & & & & \multirow{3}{*}{$3.62^{\mathrm{NS}}, 1, .057$} \\
\hline & Vegetarian & 27 & 54 & 17 & 34 & \\
\hline & Non-vegetarian & 23 & 46 & 33 & 66 & \\
\hline \multirow[t]{3}{*}{8.} & Residence & & & & & \multirow{3}{*}{$.055^{\mathrm{NS}}, 1, .8$} \\
\hline & Rural & 29 & 58 & 20 & 40 & \\
\hline & Urban & 21 & 42 & 30 & 60 & \\
\hline
\end{tabular}

(NS-non significant, ${ }^{*}$ significant at $\mathrm{p}<0.05$ )

Table.2 Frequency and percentage distribution of anaemic and non-anaemic mothers according to their clinical variables

\begin{tabular}{|c|c|c|c|c|c|c|}
\hline \multirow[t]{2}{*}{ S.No } & \multirow[t]{2}{*}{ Clinical variables } & \multicolumn{2}{|c|}{ Anaemic $\left(n_{1}=50\right)$} & \multicolumn{2}{|c|}{$\begin{array}{c}\text { Non-anaemic } \\
\left(\mathbf{n}_{2}=\mathbf{5 0}\right)\end{array}$} & \multirow[t]{2}{*}{$\mathrm{X}^{2}$, df, p-value } \\
\hline & & $\mathbf{f}_{1}$ & $\%$ & $\mathbf{f}_{2}$ & $\%$ & \\
\hline \multirow[t]{3}{*}{1.} & \multicolumn{6}{|l|}{ HB level of mother } \\
\hline & $<10 \mathrm{gm} \%$ & 50 & 100 & 00 & 00 & \multirow[t]{2}{*}{-} \\
\hline & $\geq 10 \mathrm{gm} \%$ & 00 & 00 & 50 & 100 & \\
\hline \multirow[t]{3}{*}{2.} & \multicolumn{5}{|l|}{ Gravida of mother } & \multirow{3}{*}{$23.2,1, .000^{*}$} \\
\hline & Primigravida & 23 & 46 & 25 & 50 & \\
\hline & Multigravida & 27 & 54 & 25 & 50 & \\
\hline \multirow[t]{3}{*}{3.} & \multicolumn{5}{|l|}{ Sex of the newborn } & \multirow{3}{*}{$.074^{\mathrm{NS}}, 1, .78$} \\
\hline & Boy & 24 & 48 & 24 & 48 & \\
\hline & Girl & 26 & 52 & 26 & 52 & \\
\hline \multirow[t]{4}{*}{4.} & Type of delivery & & & & & \multirow{4}{*}{$9.94,2, .04 *$} \\
\hline & Pre-term delivery & 11 & 22 & 02 & 04 & \\
\hline & Post-term delivery & 02 & 04 & 04 & 08 & \\
\hline & At-term delivery & 37 & 74 & 44 & 88 & \\
\hline
\end{tabular}


Table.3 Frequency and percentage distribution of fetal outcome among anaemic and nonanaemic mothers

\begin{tabular}{|c|c|c|c|c|c|c|}
\hline S. No & Fetal outcome & \multicolumn{2}{|c|}{$\begin{array}{c}\text { Anaemic } \\
\left(\mathbf{n}_{1}=\mathbf{5 0}\right)\end{array}$} & \multicolumn{2}{|c|}{$\begin{array}{c}\text { Non-anaemic } \\
\left(\mathbf{n}_{2}=\mathbf{5 0}\right)\end{array}$} & $\chi^{2}, \mathbf{d f}, \mathbf{p}$-value \\
\hline \multirow[t]{4}{*}{1.} & APGAR score & $\mathbf{f}_{1}$ & $\%$ & $\mathbf{f}_{2}$ & $\%$ & \multirow{4}{*}{$12.79,2, .002 *$} \\
\hline & No depression & 40 & 80 & 48 & 96 & \\
\hline & Mild depression & 07 & 14 & 02 & 04 & \\
\hline & Severe depression & 03 & 06 & 00 & 00 & \\
\hline \multirow[t]{4}{*}{2.} & \multicolumn{6}{|l|}{ Weight of newborn } \\
\hline & $<2.5 \mathrm{~kg}$ & 13 & 26 & 01 & 02 & \multirow{3}{*}{$16.01,2, .000 *$} \\
\hline & 2.5 to $3.1 \mathrm{~kg}$ & 34 & 68 & 48 & 96 & \\
\hline & $>3.1 \mathrm{~kg}$ & 03 & 06 & 01 & 02 & \\
\hline \multirow[t]{4}{*}{3.} & \multicolumn{6}{|l|}{ Temperature of newborn (axillary) } \\
\hline & $<96.8 \mathrm{~F}$ & 03 & 06 & 01 & 02 & \multirow{3}{*}{$3.34^{\mathrm{NS}}, 4, .502$} \\
\hline & $96.8-97.7^{0} \mathrm{~F}$ & 47 & 94 & 48 & 96 & \\
\hline & $>97.7^{0} \mathrm{~F}$ & 00 & 00 & 01 & 02 & \\
\hline \multirow[t]{4}{*}{4.} & \multicolumn{6}{|l|}{ Crown-heel length of newborn } \\
\hline & $<50 \mathrm{~cm}$ & 16 & 32 & 01 & 02 & \multirow{3}{*}{$18.02,1, .004^{*}$} \\
\hline & 50 to $52 \mathrm{~cm}$ & 34 & 68 & 48 & 96 & \\
\hline & $>52 \mathrm{~cm}$ & 00 & 00 & 03 & 06 & \\
\hline \multirow[t]{4}{*}{5.} & \multicolumn{6}{|l|}{ Head-circumference of newborn } \\
\hline & $<35 \mathrm{~cm}$ & 04 & 08 & 02 & 04 & \multirow[t]{3}{*}{$.98^{\mathrm{NS}}, 2, .78$} \\
\hline & 33 to $35 \mathrm{~cm}$ & 46 & 92 & 45 & 90 & \\
\hline & $>35 \mathrm{~cm}$ & 00 & 00 & 03 & 06 & \\
\hline \multirow[t]{4}{*}{6.} & \multicolumn{6}{|l|}{ Chest-circumference of newborn } \\
\hline & $<30 \mathrm{~cm}$ & 06 & 12 & 02 & 04 & \multirow{3}{*}{$.90^{\mathrm{NS}}, 4, .92$} \\
\hline & 30 to $33 \mathrm{~cm}$ & 43 & 86 & 45 & 90 & \\
\hline & $>33 \mathrm{~cm}$ & 01 & 02 & 03 & 06 & \\
\hline \multirow[t]{3}{*}{7.} & \multicolumn{6}{|l|}{ Congenital malformation } \\
\hline & Yes, specify....... & 00 & 00 & 00 & 00 & - \\
\hline & No & 50 & 100 & 50 & 100 & \\
\hline \multirow[t]{8}{*}{8.} & \multicolumn{6}{|l|}{ Genetalia of newborn } \\
\hline & \multicolumn{6}{|l|}{ Girl baby } \\
\hline & Labia is covered with labia majora & 00 & 00 & 00 & 00 & \multirow{6}{*}{$1.119^{\mathrm{NS}}, 2, .57$} \\
\hline & Labia minora is visible & 26 & 52 & 26 & 52 & \\
\hline & Clitoris is not visible & 00 & 00 & 00 & 00 & \\
\hline & \multicolumn{5}{|l|}{ Boy baby } & \\
\hline & Testis are not palpable & 00 & 00 & 00 & 00 & \\
\hline & $\begin{array}{l}\text { Scrotum is big and testis are } \\
\text { palpable }\end{array}$ & 24 & 48 & 24 & 48 & \\
\hline
\end{tabular}


Table.4 Frequency and percentage distribution of placental outcome among anaemic and nonanaemic mothers

\begin{tabular}{|c|c|c|c|c|c|c|}
\hline & & & & & & $\mathrm{N}=100$ \\
\hline S.No & Placental outcome & & & & $\begin{array}{l}\text { aemic } \\
\text { 50) }\end{array}$ & $\chi^{2}$, df, p-value \\
\hline 1. & Timing for delivery of placenta & $\mathbf{f}_{1}$ & $\%$ & $\mathbf{f}_{2}$ & $\%$ & \\
\hline & $<5$ minutes & 05 & 10 & 00 & 00 & \\
\hline & 5-20 minutes & 45 & 90 & 50 & 100 & $3.86^{\mathrm{NS}}, 2,1.45$ \\
\hline & $>20$ minutes & 00 & $\mathbf{0 0}$ & 00 & 00 & \\
\hline 2. & Weight of placenta & & & & & \\
\hline & $<500 \mathrm{gm}$ & 21 & 42 & 02 & 04 & $3.07,2, .004 *$ \\
\hline & $500 \mathrm{gm}$ & 26 & 52 & 40 & 80 & \\
\hline & $>500 \mathrm{gm}$ & 03 & 06 & 08 & 16 & \\
\hline 3. & Shape of placenta & & & & & \\
\hline & Dome shape & 04 & 08 & 00 & 00 & \\
\hline & Oval shape & 02 & 04 & 02 & 04 & $.28^{\mathrm{NS}}, 2, .86$ \\
\hline & Discoid & 44 & 88 & 48 & 96 & \\
\hline & Any other & 00 & $\mathbf{0 0}$ & 00 & 00 & \\
\hline 4. & Diameter of placenta & & & & & \\
\hline & $<15 \mathrm{c} . \mathrm{m}$ & 12 & 24 & 02 & 04 & \\
\hline & 15-20c.m & 38 & 76 & 46 & 92 & $.70^{\mathrm{NS}}, 2, .005$ \\
\hline & $>20 \mathrm{c} . \mathrm{m}$ & 00 & $\mathbf{0 0}$ & 02 & 04 & \\
\hline 5. & Thickness of placenta & & & & & \\
\hline & $<3 \mathrm{~cm}$ & 12 & 24 & 02 & 04 & \\
\hline & 3c.m & 36 & 72 & 45 & 90 & $2.52,4, .004^{*}$ \\
\hline & $>3 \mathrm{~cm}$ & 02 & 04 & 03 & 06 & \\
\hline 6. & Maternal surface lobes & & & & & \\
\hline & $<15$ lobes & 00 & 00 & 00 & 00 & - \\
\hline & 15-20 lobes & 50 & 100 & 50 & 100 & \\
\hline & $>20$ lobes & 00 & 00 & 00 & 00 & \\
\hline 7. & Condition of placenta & & & & & \\
\hline & Complete & 36 & 72 & 46 & 92 & \\
\hline & Incomplete & 14 & 28 & 04 & 08 & $1.5,1, .02 *$ \\
\hline 8. & Colour of placenta & & & & & \\
\hline & Lighter in colour than red & 03 & 06 & 01 & 02 & \\
\hline & Pallor of maternal surface & 00 & 00 & 00 & 00 & \\
\hline & Dull red and grayish & 45 & 90 & 47 & 94 & $.35^{\mathrm{NS}}, 4, .98$ \\
\hline & Green colour fetal surface & 02 & 04 & 02 & 04 & \\
\hline & Discolored or foul smelling & 00 & $\mathbf{0 0}$ & 00 & $\mathbf{0 0}$ & \\
\hline 9. & Type of placenta & & & & & \\
\hline & Normal & 50 & 100 & 50 & 100 & \\
\hline & Circumvallete & 00 & 00 & 00 & 00 & - \\
\hline & Battledore & 00 & 00 & 00 & 00 & \\
\hline & Velamentous & 00 & 00 & 00 & 00 & \\
\hline 10. & Length of umblical cord & & & & & \\
\hline & Short cord & 05 & 10 & 02 & 04 & \\
\hline & Normal & 45 & 90 & 48 & 96 & $.48^{\mathrm{NS}}, 4, .97$ \\
\hline & Long cord & 00 & $\mathbf{0 0}$ & 00 & 00 & \\
\hline 11. & Wharton's jelly in cord & & & & & \\
\hline & Present & 50 & 100 & 50 & 100 & - \\
\hline & Not present & 00 & 00 & 00 & 00 & \\
\hline 12. & Vessels of umblical cord & & & & & \\
\hline & Two arteries one vein & 50 & 100 & 50 & 100 & \\
\hline & One artery one vein & 00 & 00 & 00 & 00 & - \\
\hline & Two arteries two vein & 00 & 00 & 00 & 00 & \\
\hline & One artery two vein & 00 & 00 & 00 & 00 & \\
\hline 13. & Insertion of cord on fetal surface & & & & & \\
\hline & Lateral & 00 & 00 & 00 & 00 & $.087^{\mathrm{NS}}, 1, .76$ \\
\hline & Central & 48 & 96 & 50 & 100 & \\
\hline & Marginal & 02 & 04 & 00 & 00 & \\
\hline & In the membranes & 00 & 00 & 00 & 00 & \\
\hline
\end{tabular}


Table.5 To compare the findings of fetal outcome of anaemic and non-anaemic mothers

\begin{tabular}{|c|c|c|c|c|c|}
\hline \multirow{3}{*}{ Group } & \multicolumn{4}{|c|}{ Fetal outcome } & \multirow{3}{*}{$\begin{array}{l}\chi^{2}, \text { df, } \\
\text { p-value }\end{array}$} \\
\hline & \multicolumn{2}{|c|}{ Good } & \multicolumn{2}{|c|}{ Poor } & \\
\hline & $\mathbf{n}_{1}$ & $\%$ & $\mathbf{n}_{2}$ & $\%$ & \\
\hline Anaemic (50) & 14 & 28.0 & 36 & 72.0 & $14.463,1, .000^{*}$ \\
\hline Non-anaemic (50) & 34 & 68.0 & 16 & 32.0 & \\
\hline
\end{tabular}

$\mathrm{N}=100$

(NS-non significant, *significant at $\mathrm{p}<0.05$ )

Table.6 To compare the findings of placental outcome of anaemic and non-anaemic mothers

\begin{tabular}{|l|l|l|l|l|l|}
\hline \multirow{3}{*}{ Group } & \multicolumn{4}{|c|}{ Placental outcome } & \multirow{2}{*}{$\begin{array}{c}\text { 2, df, } \\
\end{array}$} \\
\cline { 2 - 5 } & Good & \multicolumn{3}{|c|}{ poor } & \\
\cline { 2 - 5 } & $\mathbf{n}_{\mathbf{1}}$ & $\mathbf{\%}$ & $\mathbf{n}_{\mathbf{2}}$ & $\mathbf{\%}$ & \\
\hline Anaemic & $\mathbf{9}$ & $\mathbf{1 8 . 0}$ & 41 & 82.0 & $\mathbf{7 . 7 6 7 , 1 , 0 0 5 *}$ \\
\hline Non-anaemic & $\mathbf{2 3}$ & $\mathbf{4 6 . 0}$ & 27 & 54.0 & \\
\hline
\end{tabular}

$\mathrm{N}=100$

(NS-non significant, *significant at $\mathrm{p}<0.05$ )

Table.7 Association of fetal outcome in anaemic and non-anaemic mothers with selected sociodemographic variables

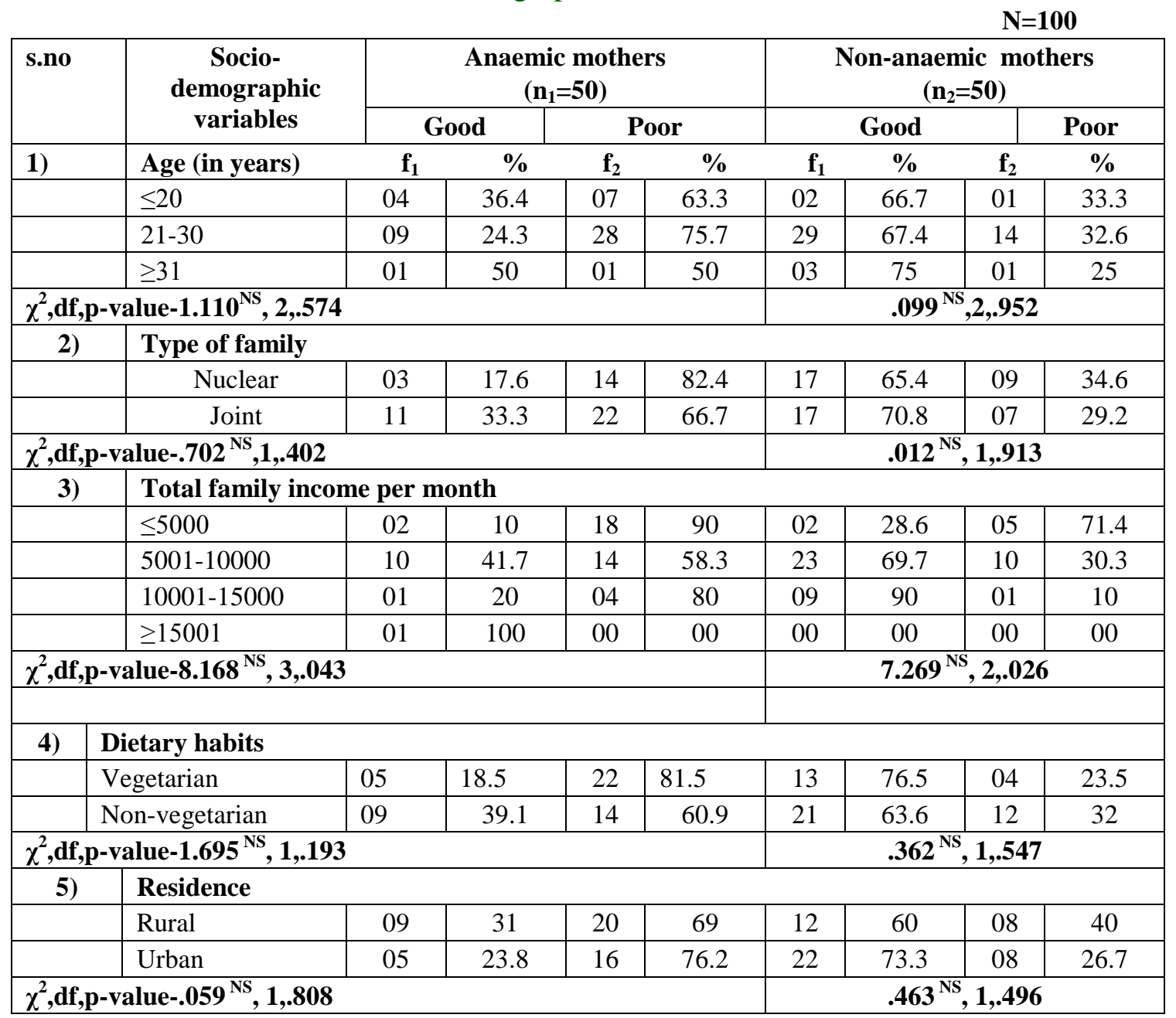

NS-non significant; $p>0.05$ 
Table.8 Association of placental outcome in anaemic and non-anaemic mothers with selected socio-demographic variables

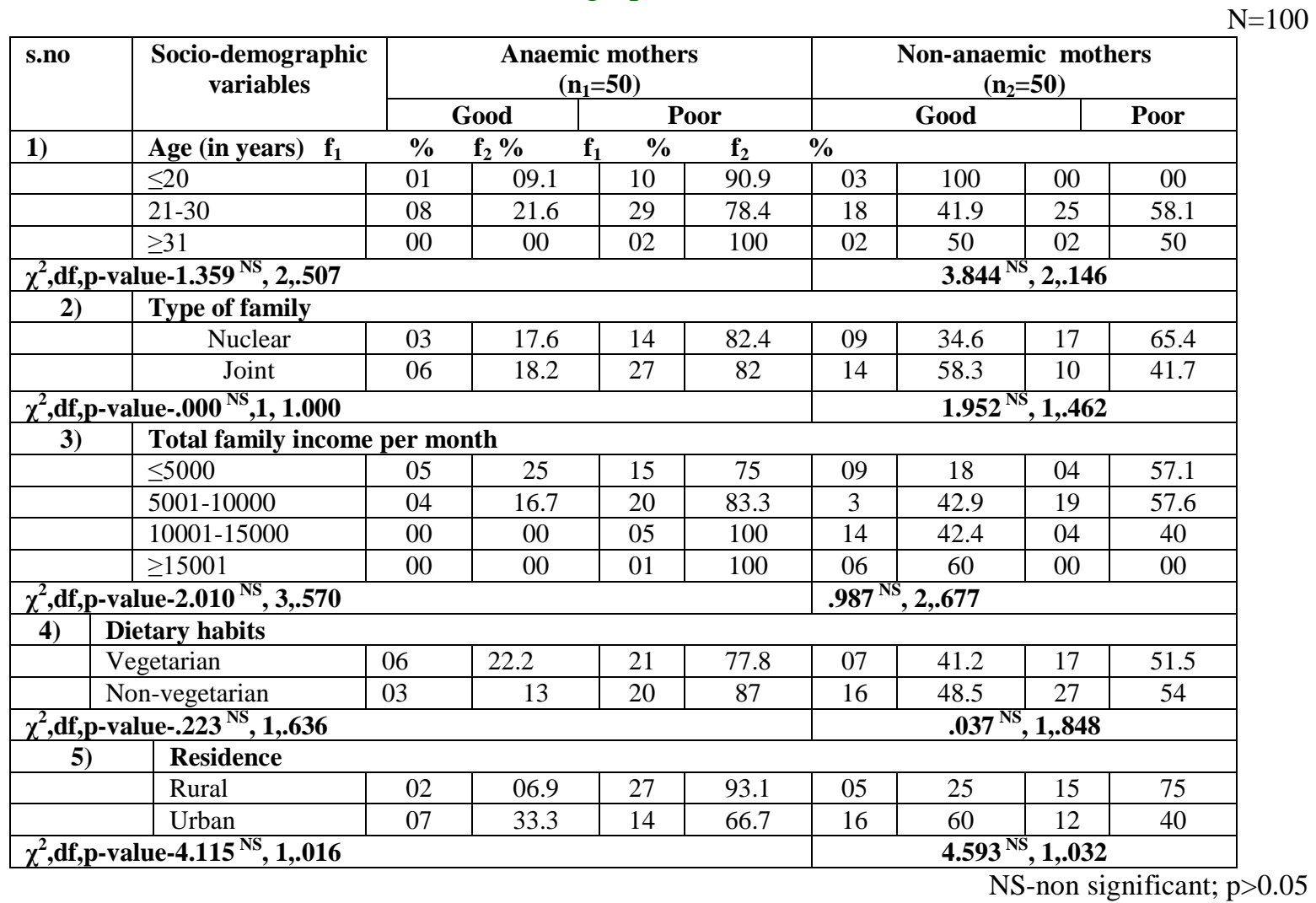

In anaemic mothers out of 50 mothers $18.0 \%$ had good placental outcome and $82.0 \%$ had poor placental outcome and in non-anaemic mothers out of 50 mothers $46.0 \%$ had good placental outcome and $54.0 \%$ had poor placental outcome (Tables 5 and 6).

Section VI: Findings related to the association with demographic variables

\section{Calculated $\chi^{2}$ value showed that}

There was no significant association between fetal outcome and placental outcome according to the age of mothers, type of family, total family income per month, dietary habits and residence of mothers.

To compare the fetal outcome and placental outcome in anaemic and non-anaemic mothers.
Based on the objective of the study in anaemic mothers out of 50 mothers, $28.0 \%$ had good fetal outcome and $72.0 \%$ had poor fetal outcome and in non-anaemic mothers out of 50 mothers $68.0 \%$ had good fetal outcome and $32.0 \%$ had poor fetal outcome.

Based on the objective of the study, in anaemic mothers out of 50 mothers, $18.0 \%$ had good placental outcome and $82.0 \%$ had poor placental outcome and in non-anaemic mothers out of 50 mothers $46.0 \%$ had good placental outcome and $54.0 \%$ had poor placental outcome.

The present study findings were supported with the comparative study to assess placental weight and fetal outcome among normal and anaemic mothers. Purposive sampling technique was used, sample size was 20 normal and 20 anaemic mothers who are 
admitted in labour room for the delivery at selected hospitals of Bijapur.

The study was competed in 6-7 weeks and it showed that $67 \%$ anaemic mothers had less placental weight and fetal outcome and 92\% normal had good placental weight and good fetal outcome (Tables 7 and 8).

In present study, Fetal outcome were poor APGAR score, Weight of new-born, crownheel length and Poor Placental outcome were weight of placenta, thickness of placenta, condition of placenta present in the anaemic mothers baby and placenta.

The findings of study revealed that there is need to enhance knowledge regarding importance of diet during antenatal time.

There are many $\mathrm{MCH}$ programs are organised by Government of India regarding prevention of anaemia and ASHA workers are also there who provide health related information to the mothers and regular visit to hospital reduces the risk of anaemia. It was enlighten study experience.

\section{References}

Brunner and Sudharth. Text book of Medical Surgical Nursing. Ed. $11^{\text {th }}$. vol. 2 . Wolters Kluwer.

Dutta, D.C., "Text book of Gynecology", 5th edition, New central agency $\mathrm{p}(\mathrm{ltd})$, Kolkata.

Melinamani. Anaemia and its effect on fetus and placenta. Rajiv Gandhi university of health sciences. 2014

Perry, E.S., Lowder milk DL. Maternity and Women's health. London: Mosby Year Book; 2004.P.402

Perry, E.S., Lowder milk DL. Maternity and Women's health. London: Mosby Year Book; 2004.P.402.

Raja Gangopadhyaya, Mahantesh K, Louis Keith. Anaemia and pregnancy a link to maternal chronic diseases. International Journal of Obstetrics and Gynaecology. 2011; 511-5.

\section{How to cite this article:}

Anupama Sharma, Madan Lal, Vill Malehri and Dangar, P.O. 2017. A Comparative Study to Assess the Fetal and Placental Outcome among Anaemic and Non-Anaemic Mothers of Selected Hospital of District Mohali, Punjab, India. Int.J.Curr.Microbiol.App.Sci. 6(9): 28142823. doi: https://doi.org/10.20546/ijcmas.2017.609.346 